Klinichna khirurhiia. 2018 October;85(10):26-28.

DOI: $10.26779 / 2522-1396.2018 .10 .26$

\title{
Мультимодальна покрокова тактика хірургічного лікування хворих з гострим некротичним панкреатитом
}

\author{
І. В. Хомяк ${ }^{1}$, О. В. Ротар ${ }^{2}$, В. I. Ротар ${ }^{2}$, А. I. Хомяк ${ }^{1}$ \\ ${ }^{1}$ Національний інститут хірургії та трансплантології імені О. О. Шалімова НАМН України, м. Київ, \\ ${ }^{2}$ Буковинський державний медичний університет, м. Чернівці

\section{Multimodal staged tactics of surgical treatment in patients, suffering an acute necrotic pancreatitis}

\author{
I. V. Khomiak ${ }^{1}$, O. V. $\operatorname{Rotar}^{2}$, V. I. $\operatorname{Rotar}^{2}$, A. I. Khomiak \\ ${ }^{1}$ Shalimov National Institute of Surgery and Transplantology, Kyiv, \\ ${ }^{2}$ Bukovyna State Medical University, Chernivtsi
}

\begin{abstract}
Реферат
Мета. Оцінити ефективність розробленої тактики мультимодального покрокового хірургічного лікування гострого некротичного панкреатиту (ГНП).

Матеріали і методи. Проаналізовано результати лікування 317 хворих з ГНП, яким протягом 2013-2017 рр. 3астосовували запропоновану тактику виконання хірургічних втручань. Для оцінки ефективності лікування вивчали вперше виявлену органну недостатність (ОН) після операції, тривалість інтенсивної терапії, післяопераційні ускладнення та летальність. Результати. Застосування запропонованої тактики забезпечило зменшення частоти виконання широкої лапаротомної некрсеквестректомії до 14,5\% та відтермінування його на строк після 4-го тижня від початку захворювання у 82,6\% оперованих пацієнтів. У післяопераційному періоді ускладнення спостерігали у 28,3\% пацієнтів, загальна летальність становила 3,5\%, після виконання широких лапаротомних некрсеквестректомій - 6,5\%.

Висновки. Використання мультимодальної покрокової тактики хірургічного лікування хворих з ГНП забезпечує зменшення частоти виконання широкої лапаротомної некрсеквестректомії та частоти виникнення післяопераційних ускладнень

Ключові слова: гострий некротичний панкреатит; мініінвазивні втручання; еховідеоендоскопія; мультимодальна по-
\end{abstract} крокова тактика.

Abstract

Objective. To estimate the efficacy of the tactics elaborated for the multimodal staged surgical treatment of an acute necrotic pancreatitis (ANP).

Materials and methods. There were studied the results of treatment of 317 patients, suffering ANP, to whom in 2013-2017 yrs a proposed tactics of the surgical interventions performance was applied. For estimation of the treatment efficacy there were analyzed the organ's insufficiency, revealed for the first time after the operation, the intensive therapy duration, postoperative complications and lethality.

Results. Application of tactics proposed have provided the performance rate of wide laparotomic necrsequestrectomy down to $14.5 \%$ and its deferment till after the fourth week from the disease beginning in $82.6 \%$ operated patients. In postoperative period the complications were observed in $28.3 \%$ patients, general lethality have constituted $3.5 \%$, while after performance of wide laparotomic necrsequestrectomies $-6.5 \%$.

Conclusion. Application of a multimodal staged surgical treatment of patients, suffering an ANP, provides the rate reduction for performance of wide laparotomic necrsequestectomy and a morbidity rate as well.

Keywords: acute necrotic pancreatitis; miniinvasive interventions; echo-videoendoscopy; multimodal staged tactics.

Незважаючи на прогрес у діагностиці, консервативному і хірургічному лікуванні ГНП, летальність при його тяжких формах коливається в межах від 15 до 45\% [1]. Водночас погляди на місце, роль та методи хірургічних втручань при ГНП значно різняться, немає єдиної точки зору щодо показань до використання мінінвазивних методів лікування та лапаротомної некрсеквестректомії залежно від тривалості захворювання, розповсюдженості, характеру і локалізації патологічних вогнищ [2 - 4].

Мета дослідження: оцінити ефективність розробленої мультимодальної покрокової тактики хірургічного лікування ГНП

\section{Матеріали і методи дослідження}

Проаналізовано результати лікування 317 хворих з ГНП у клініці Національного інституту хірургії та транспланто- логії імені О. О. Шалімова, яким протягом 2013 - 2017 рр. застосовували покрокову хірургічну тактику з переважним використанням мініінвазивних технологій. Жінок було 145 (45,7\%), чоловіків - 172 (54,3\%) віком від 18 до 78 років. Середній вік пацієнтів становив (48 \pm 1$)$ рік.

Діагноз ГНП встановлювали на основі анамнезу, клінічної картини, даних лабораторних (рівні амілази крові і діастази сечі) та інструментальних - ультразвукового дослідження (УЗД) та контрастно підсиленої комп'ютерної томографії (КТ) - методів дослідження. Ступінь тяжкості ГНП оцінювали згідно з рекомендаціями групи 3 перегляду класифікації гострого панкреатиту (Атланта, 1992) інтернаціональним консенсусом у 2012 році [5] за наявністю транзиторної або постійної ОН та за шкалою APACHE II (Acute Physiology and Chronic Health Evaluation II). Для визначення ступеня ОН оцінювали функцію ди- 
хальної, серцево-судинної систем і нирок за модифікованою шкалою Маршалла, неврологічну недостатність за шкалою ком Глазго [6]. Інфікування вогнищ панкреонекрозу діагностували за ознаками синдрому системної запальної відповіді (ССЗП), даними КТ, бактеріологічного дослідження, позитивним прокальцитоніновим або пресепсиновим тестом [7].

Усім хворим проводили індивідуально підібрану консервативну терапію, основними принципами якої були: знеболювання, корекція порушень центральної гемодинаміки та периферійного кровообігу, раннє ентеральне харчування, адекватне білково-енергетичне забезпечення, профілактика розвитку гнійної інфекції, пригнічення секреторної активності підшлункової залози (П3), дезінтоксикаційна терапія, корекція імунних розладів, профілактика утворення стресових виразок, гепатопротекція [8].

Для оцінки ефективності хірургічного лікування хворих з ГНП вивчали вперше виявлену післяопераційну ОН, тривалість інтенсивної терапії після операції, інфекційні і післяопераційні ускладнення, післяопераційну летальність.

\section{Результати}

Лікування ГНП в усіх фазах розпочинали з консервативної терапії, обсяг якої визначали з урахуванням тяжкості стану хворих під час госпіталізації та ризику розвитку ускладнень, для чого використовували шкалу BISAP (The Bedside Index for Severity in Acute Pancreatitis) та piвень розчинних рецепторів SCD14 [7]. Хірургічне лікування проводили послідовно, як перший крок застосовували діапевтичні ендоскопічні або черезшкірні втручання залежно від локалізації та морфологічної характеристики патологічних вогнищ. Ехоконтрольовані ендоскопічні втручання застосовували як початкове інвазивне лікування у 69 пацієнтів у разі прилягання патологічних вогнищ до шлунка або дванадцятипалої кишки (ДПК). За умови їх відмежування ефективність методу становила 87,2\%. У пацієнтів із гострими некротичними скупченнями перевагу надавали черезшкірним пункціям та встановленню силіконових дренажів діаметром 10-12 Fr під контролем УЗД, які за умови активного лікування у 81,1\% пацієнтів були остаточним інвазивним втручанням. У післяопераційному періоді всім пацієнтам призначали етіотропну антибіотикотерапію за результатами регулярного бактеріологічного дослідження некротичних мас, ефективність якої оцінювали за активністю проявів ССЗВ та динамікою змін біологічних маркерів - C-реактивного протеїну, прокальцитоніну та пресепсину. У разі застосування черезшкірних методів потреба в повторних втручаннях виникла в 64,5\% спостережень, а у разі використання ендоскопічного доступу - в 21,3\% спостережень ( $<$ 0,05) через недостатнє дренування некротичних мас та прогресування гнійно-запального процесу. Неефективність діапевтичних втручань була спричинена ураженням понад 30\% П3, наявністю декількох некротичних вогнищ та їх великим об'ємом із переважанням твердого вмісту. Якщо дренування вмісту некротичного вогнища було недостатньо ефективним, розширяли канал, по якому був введений дренаж, та замінювали його на дренаж більшого діаметра. У 10 пацієнтів з великими розмірами патоло- гічних вогнищ використовували альтернативний (ендоскопічний або черезшкірний відповідно) доступ для повторного діапевтичного втручання. Одночасно за даними антибіотикограм корегували антибактеріальну терапію.

Тільки у разі неефективності діапевтичних методів, обумовленої декількома чинниками, переходили до наступного більш інвазивного кроку - застосування мініінвазивної некрсеквестректомії. У строк до 4-го тижня захворювання перевагу надавали позаочеревинному доступу до уражених ділянок, для чого у 8 пацієнтів використовували люмботомну відеоконтрольовану санацію за допомогою нефроскопа. За наявності відмежованих патологічних вогнищ, що прилягали до шлунка або ДПК, у 23 пацієнтів виконали ендоскопічну некрсеквестректомію під ехоендоскопічним контролем. Втручання виконували індивідуалізовано. Якщо кількість твердого компонента була незначною, некрсеквестректомію закінчували введенням двох двобічних дренажів типу pig-tale (7 спостережень). За наявності великої кількості гнійних мас у порожнину вводили цистоназальний зонд, через який підключали систему для безперервного лаважу фізіологічним розчином у післяопераційному періоді (8 спостережень). Ми вперше 8 пацієнтам, у яких щільність капсули навколо патологічного вогнища була недостатньою, а детрит був у великій кількості, застосували покриті металеві стенти, що самі розпрямляються, для виконання адекватної та безпечної некрсеквестректомії. Вже після першого ендоскопічного втручання спостерігали клінічне покращення із зменшенням ознак ССЗВ та ОН в усіх спостереженнях.

У 26 пацієнтів із поширеними ураженнями П3 та запливами в заочеревинний простір ми вперше застосували комбінований ретроперитонеально-відеоендоскопічний доступ, в якому поєднані переваги ендоскопічного та люмботомного відеоконтрольованого методів некрсеквестректомії. На першому етапі під контролем УЗД встановлювали черезшкірний дренаж, на другому - за допомогою еховідеоендоскопа виконували пункцію утворення через стінку шлунка або ДПК та, за необхідності, налагоджували його внутрішнє дренування з використанням пластикових або металевих стентів. Метод виявився високоефективним при тяжких та поширених ураженнях, у 92\% пацієнтів після його використання не виникло потреби в подальших втручаннях.

У разі неможливості застосування перерахованих втручань або їх недостатньої ефективності переходили до наступного кроку, а саме до виконання відкритої лапаротомної некрсеквестректомії. Нами розроблена техніка селективних мінілапаро- та мінілюмботомій, використання яких зменшувало травматичність операції. Показаннями до їх виконання були невеликі (до 7 см у діаметрі) нагноєні відмежовані вогнища панкреонекрозу. Селективні «відкриті» мініінвазивні втручання застосовані у 12 хворих, необхідність у більш інвазивному лікуванні виникла тільки у 2 із них. Широку лапаротомну панкреатонекрсеквестректомію виконали у 46 пацієнтів. У 40 пацієнтів втручання виконували після застосування діапевтичних черезшкірних або ендоскопічних втручань, вони були останнім етапом у запропонованій нами покроковій тактиці хірургічного лікування ГНП. У 6 хворих, які були госпіталізовані 
або переведені з інших лікувальних закладів у строки після 4-го тижня від початку захворювання та мали поширені нагноєні відмежовані ураження із клінічною картиною сепсису, виконали лапаротомні втручання як перший та остаточний етап хірургічного лікування.

У післяопераційному періоді ускладнення спостерігали у 28,3\% пацієнтів: нові прояви ОН (7 спостережень), арозивну кровотечу (4), панкреатичні та дуоденальні нориці (6). Загальна летальність становила 3,5\%, після застосування широких лапаротомних некрсеквестректомій - 6,5\%.

\section{Обговорення}

Отримані нами результати засвідчили, що успішне хірургічне лікування ГНП потребує індивідуалізованого підходу, який включає інтенсивну терапію та покрокове мультимодальне застосування нових методів інвазивного лікування. Важливим принципом хірургічної тактики лікування ГНП має бути відтермінування оперативного втручання доти, поки некротичні скупчення добре не відмежуються. Мініінвазивні діапевтичні втручання слід виконувати як перший крок хірургічного лікування, особливо якщо потреба в них виникає в перші тижні захворювання [9]. Якщо таке мініінвазивне хірургічне втручання $є$ недостатньо ефективним, його необхідно повторити, використовуючи інший альтернативний доступ. Якщо неможливо ефективно контролювати вогнище інфекції, варто переходити до наступного кроку - мініінвазивної некрсеквестректомії. Протягом перших 4 тижнів захворювання перевагу слід віддавати транслюмбальній відеоконтрольованій санації за допомогою нефроскопа, а після відмежування вогнищ некрозу можна використовувати також ендоскопічні та комбіновані методи мініінвазивної некрсеквестректоміі. Подальшим кроком хірургічного лікування у разі невеликих розмірів патологічних вогнищ $е$ застосування селективних мінілапаро- та мінілюмботомічних некрсеквестректомій. Якщо після послідовного застосування перерахованих мініінвазивних хірургічних втручань захворювання прогресує або з'являються редуковані фази ГНП із швидким утворенням заочеревинного нагноєння, збільшенням тяжкості інтоксикації, виникненням хірургічних ускладнень, необхідно переходити до останнього кроку - виконання широкої лапаротомії.

Застосування розробленої нами тактики сприяло відмежуванню патологічного процесу, виконанню відстро- ченої панкреатонекрсеквестректомії з мінімальним ризиком для пацієнта, зменшенню частоти післяопераційних ускладнень та летальності.

\section{Висновки}

1. Використання запропонованого покрокового мультимодального алгоритму мініінвазивного хірургічного лікування в поєднанні з консервативною терапією дало змогу скоротити частоту виконання широких лапаротомних некрсеквестректомій до 14,5\% та відтермінувати його на строк після 4-го тижня від початку захворювання у 82,6\% оперованих пацієнтів.

2. Індивідуалізований етапний підхід до хірургічного лікування хворих з ГНП з урахуванням особливостей перебігу захворювання та фази розвитку гострого панкреатиту дав змогу знизити частоту розвитку післяопераційної ОН до 15,2\%, а післяопераційну летальність до 6,5\%.

\section{References}

1. Phillip V, Steiner JM, Algül H. Early phase of acute pancreatitis: assessment and management. World J Gastrointest Pathophys. 2014 May;5(3):158-64. doi: 10.4291/wjg.v5.i3.158.

2. Alsfasser G, Schwandner F, Pertschy A, Hauenstein K, Foitzik T, Klar E. Treatment of necrotizing pancreatitis: redefining the role of surgery. World J Surg. 2012 Oct; 36(5):1142-7. doi: 10.1007/s00268-012-1504-5.

3. Poves I, Burdio F, Dorcaratto D, Grande L. Minimally invasive techniques in the treatment of severe acute pancreatitis. Cent Eur J Med. 2014 Aug;9(4):580-5. doi: 10.2478/s11536-013-0283-1.

4. Busquets J, Pelaez N, Secanella L. Evolution and results of the surgical management of 143 cases of severe acute pancreatitis in areferral center. Cir Esp. 2014 Sept;92(9):595-603. doi: 10.1016/j.cireng.2014.04.005.

5. Working Group IAP/APA Acute Pancreatitis Guidelines. IAP/APA evidence-based guidelines for the management of acute pancreatitis. Pancreatology. 2013 Jun;13(Suppl.1):e1-e15. doi: 10.1016/j.pan.2013.07.063.

6. Banks PA, Bollen TL, Dervenis C, Gooszen HG, Johnson CD, Sarr MG, et al. Classification of acute pancreatitis 2012: revision of the Atlanta classification and definitions by international consensus. Gut. 2013 Jan;62(1):102-11. doi: 10.1136/gutjnl-2012-302779.

7. Rotar OV, Khomiak IV, Nazarchuk MF, Rotar VI, Khomiak AI. Prognosis and early diagnosis of local and systemic infected complications of acute necrotizing pancreatitis. Pancreatology 2018 June; 18(4 Suppl):169. doi: 10.1016/j.pan.2018.05.457.

8. Tenner S, Baillie J, DeWitt J, Vege SS. American College of Gastroenterology guideline: management of acute pancreatitis. Am J Gastroenterol. 2013 Jul;108(6):1400-16. doi: 10.1038/ajg.2013.218.

9. Bakker OJ, van Santvoort HC, van Brunschot S, Geskus RB, Besselink MG, Bollen TL, et al. Endoscopic transgastric versus surgical necrosectomy for infected necrotizing pancreatitis: a randomized trial. JAMA 2012 Mar;307(10):1084-5. doi: 10.1001/jama.2012.276. 